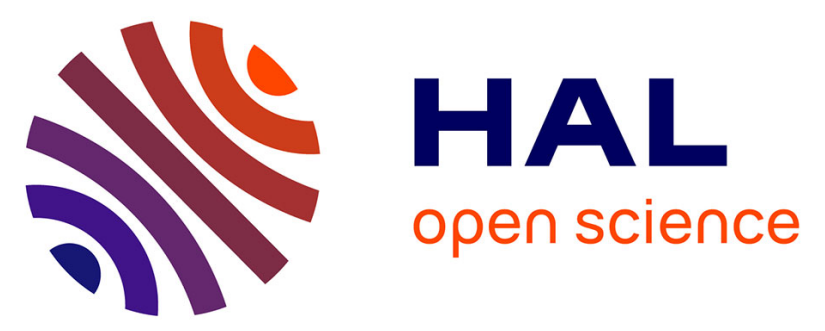

\title{
Characterisation of water transfer in a low temperature convective wood drier: influence of the operating parameters on the mass transfer coefficient
}

\author{
L. Chrusciel, E Mougel, A Zoulalian, T. Meunier
}

\section{- To cite this version:}

L. Chrusciel, E Mougel, A Zoulalian, T. Meunier. Characterisation of water transfer in a low temperature convective wood drier: influence of the operating parameters on the mass transfer coefficient. Holz als Roh - und Werkstoff, 1999, 10.1007/s001070050070 . hal-01765065

\section{HAL Id: hal-01765065 \\ https://hal.univ-lorraine.fr/hal-01765065}

Submitted on 12 Apr 2018

HAL is a multi-disciplinary open access archive for the deposit and dissemination of scientific research documents, whether they are published or not. The documents may come from teaching and research institutions in France or abroad, or from public or private research centers.
L'archive ouverte pluridisciplinaire HAL, est destinée au dépôt et à la diffusion de documents scientifiques de niveau recherche, publiés ou non, émanant des établissements d'enseignement et de recherche français ou étrangers, des laboratoires publics ou privés. 


\title{
Characterisation of water transfer in a low temperature convective wood drier: influence of the operating parameters on the mass transfer coefficient
}

\author{
L. Chrusciel, E. Mougel, A. Zoulalian, T. Meunier
}

Different drying cycles were performed in a low temperature convective and homogeneous wood drier in order to evaluate the influence of four operating parameters (wood thickness, air velocity, air temperature and air humidity) on the global mass transfer coefficient. The wood species used in this study was spruce (Picea abies Karst.). From the synthesis of the results, a general correlation has been obtained permitting to accurately calculate this transfer coefficient. Moreover, it justified the use of the simple mathematical model chosen to represent the variations of the parameters characterising the wood and air during a drying cycle.

\section{Charakterisierung des Wasserflusses in einem Niedrigtemperatur-Trockner: Einfluß der Variablen auf den Koeffizienten für Massentransport}

In der Absicht, den Einfluß von vier Variablen (Holzdichte, Luftgeschwindigkeit, Lufttemperatur und Luftfeuchte) auf den Koeffizienten für Massentransport zu bestimmen, wurden verschiedene Trocknungszyklen in einem homogenen Niedrigtemperatur-Trockner durchgeführt. Die hierfür verwendete Holzart war Fichte (Picea abies Karst). Im Anschluß an die Zusammenfassung der Ergebnisse wurde eine allgemeine Korrelation, mit der dieser Koeffizient auf eine bestimmte Weise berechnet werden kann, erzielt. Diese rechtfertigte die Wahl eines einfachen Simulationsmodells, das die Veränderung der charakteristischen Luft- und Holz- parameter während der Trocknung darstellt.

$\begin{array}{ll}\text { List of symbols } \\ A & \text { Constant } \\ a_{0} & \text { Constant } \\ B & \text { Constant } \\ b_{0} & \text { Constant } \\ c_{0} & \text { Constant } \\ C p & \text { Specific heat, } \mathrm{J} \cdot \mathrm{kg}^{-1} \cdot \mathrm{K}^{-1} \\ D & \text { Diffusion coefficient of water in wood, } \mathrm{m}^{2} \cdot \mathrm{s}^{-1} \\ e & \text { Wood thickness, } \mathrm{mm} \\ G & \text { Mass flow rate of dry air, } \mathrm{kg} \cdot \mathrm{s}^{-1} \\ h & \text { Heat transfer coefficient, } \mathrm{w} \cdot \mathrm{m}^{-2} \cdot \mathrm{K}^{-1}\end{array}$

L. Chrusciel, E. Mougel, A. Zoulalian

ENSTIB, LERMAB, Univ. H. Poincaré

Nancy 1, BP 1041, F-88051 Epinal cedex 9, France

T. Meunier

EDF - DER département systèmes énergétiques

Centre de Recherches Les Renardières - BP 1, France $i \quad$ Iterative variable

$k_{\mathrm{G}}$ Partial mass transfer coefficient in the gas phase, $\mathrm{kg} \cdot \mathrm{m}^{-2} \cdot \mathrm{s}^{-1}$

$k_{\mathrm{S}}$ Partial mass transfer coefficient in the solid phase, $\mathrm{kg} \cdot \mathrm{m}^{-2} \cdot \mathrm{s}^{-1}$

$k_{X}$ Global mass transfer coefficient, $\mathrm{kg} \cdot \mathrm{m}^{-2} \cdot \mathrm{s}^{-1}$

$M \quad$ Mass of wood, $\mathrm{kg}$

$m$ Repartition coefficient, /

$m_{\mathrm{F}}$ Final mass of a piece of wood, $\mathrm{kg}$

$M_{\mathrm{W}}$ Oven dry mass of wood, kg

$N$ Number of wood pieces in the drier, /

$p$ Constant

$\mathrm{Rh}$ Air relative humidity, \%

$S$ Exchange surface between wood and air, $\mathrm{m}^{2}$

T Air temperature, $\mathrm{K},{ }^{\circ} \mathrm{C}$

$t$ Wood temperature, $\mathrm{K},{ }^{\circ} \mathrm{C}$

$v$ Air velocity, $\mathrm{m} \cdot \mathrm{s}^{-1}$

$w \quad$ Air moisture content, $\mathrm{kg} \cdot \mathrm{kg}^{-1}$

$x_{\mathrm{F}} \quad$ Final moisture content of a piece of wood, $\mathrm{kg} \cdot \mathrm{kg}^{-1}$

$x_{\mathrm{FSP}}$ Wood moisture content at the fibre saturation point, $\mathrm{kg} \cdot \mathrm{kg}^{-1}$

Wood moisture content, $\mathrm{kg} \cdot \mathrm{kg}^{-1}$

$x^{*} \quad$ Equilibrium moisture content, $\mathrm{kg} \cdot \mathrm{kg}^{-1}$

$z \quad$ Residual air desiccation ratio, /

\section{Greek letters}

$\alpha \quad$ Constant

$\Lambda$ Latent heat of water in wood at the temperature $t$, $\mathrm{J} \cdot \mathrm{kg}^{-1}$

$\Lambda_{0} \quad$ Latent heat of water in air at $T=0{ }^{\circ} \mathrm{C}, \mathrm{J} \cdot \mathrm{kg}^{-1}$

$\tau$ Time, $s$

\begin{tabular}{ll}
\multicolumn{2}{l}{ Subscripts } \\
a & Air \\
b & Wood \\
C & Core \\
I & Drier input \\
O & Drier output \\
0 & Initial time \\
S & Surface \\
w & Water
\end{tabular}

Exponents

L Liquid phase

V Vapour phase

1

\section{Introduction}

In the wood industry, the control of a drying cycle requires knowing the variations of the wood moisture content. It is 
very common to follow these variations by electrical needle electrodes method. As specified by the US Forest Products Laboratory (1974) or by Joly and More-Chevalier (1980), experience has shown that these probes do not permit to obtain accurate values of the average wood moisture content during drying. Moreover, the measurements by needle electrodes are limited in the range $6-30 \%$. The major drawback of these probes is relative to their operating mode. Since wood is a heterogeneous material, therefore wood moisture content measurements have only local significance. Consequently, a great number of these probes are required to measure satisfactorily the average wood moisture content. From a technical point of view, this approach is unreasonable and the kiln operators in the wood industry ciecumvent this problem by empirical knowledge (they often increase the duration of a drying cycle in order to be sure that the final wood moisture content has really been obtained) and by measuring the difference between the input and output air temperature.

Because it is difficult to obtain accurate values of wood moisture content without damage, it can be calculated. In the past, investigations concerning the modelling of wood drying have been made. To describe the transfer of water vapour and of bound water, Fick's law is often used, which requires knowledge of the water diffusion coefficient. The work of Hernandez and Puiggali (1994) modelling the drying of a hygroscopic capillary-porous media with application to softwood, has to be mentioned. Various processes are simulated, and in particular convective drying at different temperatures below $100^{\circ} \mathrm{C}$. The study concerning lumber drying presented by Bramhall (1979) is very complete: all the physical parameters are considered and expressed by mathematical relations. The author, as well as later Simpson (1991), presents the coefficient of diffusion as a function of wood moisture content rather than integrating the influence of the temperature as Stamm (1964). Many empirical correlations permitting to calculate this coefficient of diffusion exist. But as underlined by Moschler and Martin (1968), the value of this coefficient strongly depends on the method developed to measure it. Consequently, the use of these correlations seems to be very restrictive. Another way to model wood drying is to introduce a convective mass transfer coefficient like Gui et al. (1994). The model developed by the authors includes the non-homogeneous properties of wood. At present, the tendency in the research is to add equations in order to improve the accuracy of modelling and to take the orthotropicity of wood material into account. It must be underlined that the representations of mass transfer during wood drying are thereby very sophisticated from a conceptual point of view and have too strong a dependence on the values of parameters introduced in the model and describing transfer.

These are the reasons why a simple model was developed in order to represent heat and mass transfers characterised by two global coefficients. It was shown in a previous study (Karabagli et al., 1997) that the working of a low temperature convective and homogeneous wood drier can be satisfactorily represented by a model in which the wood and air moisture contents verify the system of equations resulting from: the mass balance of water in drying air
$G \cdot\left(w_{\mathrm{O}}-w_{\mathrm{I}}\right)=k_{X} \cdot S \cdot\left(x-x^{*}\right)$

the enthalpy balance on drying air

$$
\begin{aligned}
G \cdot & {\left[C p_{\mathrm{a}} \cdot\left(T_{\mathrm{O}}-T_{\mathrm{I}}\right)+\Lambda_{0} \cdot\left(w_{\mathrm{O}}-w_{\mathrm{I}}\right)\right.} \\
& \left.+C p_{\mathrm{w}}^{\mathrm{V}} \cdot\left(w_{\mathrm{O}} \cdot T_{\mathrm{O}}-w_{\mathrm{I}} \cdot T_{\mathrm{I}}\right)\right] \\
\quad & =k_{X} \cdot S \cdot \Lambda \cdot\left(x-x^{*}\right)-h \cdot S \cdot\left(T_{\mathrm{O}}-t_{\mathrm{O}}\right)
\end{aligned}
$$

the mass balance of water in wood

$-M_{\mathrm{W}} \cdot \frac{\mathrm{d} x}{\mathrm{~d} \tau}=k_{X} \cdot S \cdot\left(x-x^{*}\right)$

the enthalpy balance of wood

$$
\begin{aligned}
M_{\mathrm{W}} & \cdot\left[C p_{\mathrm{b}}+x \cdot C p_{\mathrm{w}}^{\mathrm{L}}\right] \cdot \frac{\mathrm{d} t}{\mathrm{~d} \tau} \\
= & -G \cdot\left[C p_{\mathrm{a}} \cdot\left(T_{\mathrm{O}}-T_{\mathrm{I}}\right)+\left(w_{\mathrm{O}}-w_{\mathrm{I}}\right)\right. \\
& \left.\cdot\left(-\Lambda_{0}-C p_{\mathrm{w}}^{\mathrm{L}} \cdot t\right)+C p_{\mathrm{w}}^{\mathrm{V}} \cdot\left(w_{\mathrm{O}} \cdot T_{\mathrm{O}}-w_{\mathrm{I}} \cdot T_{\mathrm{I}}\right)\right]
\end{aligned}
$$

In the equations above, the transfer of water between wood and air is characterised by the mass transfer coefficient $k_{X}$, considered as a constant during drying. The different drying cycles studied in the past have shown that wood species do not have a significant influence on the value of the coefficient $k_{X}$. In order to be able to use the model presented above in many different conditions of drying, the influence of the main operating parameters (characterising drying) on the mass transfer coefficient is investigated first. A general correlation obtained from the synthesis of all the results is then proposed to allow the evaluation of the global mass transfer coefficient in function of the operating parameters considered.

\section{2}

\section{Materials and methods}

\section{1}

\section{Experimental apparatus}

The experimental work of this study was carried out on a wood drier which is similar, considering its process, to industrial driers: the major difference concerns its size and its probes equipment. Indeed, the average capacity of industrial driers is some ten cubic meters versus only 0.4 cubic meter for the drying cell used in this study (see scheme, Fig. 1).

For drying, the wood is stacked in the drying cell $S$ crossed by an air flow whose input humidity and temperature are regulated. A vapour generator $G$ and an electric resistance $R$ are situated on the main circuit of the equipment. A condenser $C$ is positioned on the dehydration circuit. The function of these three devices is to increase or to decrease the temperature and humidity of the drying air. The air flow in the main circuit is blown by a ventilator $V$. Depending on the opening of the two sluices $V p$ and $V d$, the rate of the drying air flow can vary between 600 and $2000 \mathrm{~m}^{3} / \mathrm{h}$.

Several variables were measured during a drying cycle: the temperature, relative humidity and the rate of the air flow in both the main circuit and dehydration circuit, and the mass of wood. Three thermocouples are disposed at the points 1,2 and 3 of the drying plant (see Fig. 1), two 